\title{
The Relation between Length of the Cell Cycle Duration and RNA Content in HeLa S3 Cells
}

\author{
Kohzaburo Fujikawa-Yamamoto \\ Central Laboratory, Kanazawa Medical University, Uchinada, Ishikawa 920-02, \\ Japan
}

\begin{abstract}
The cell cycle of HeLa S3 cells synchronized by hydroxyurea was investigated by flow cytometry. Metachromatic fluorochrome acridine orange was used to strain the DNA and RNA of the cells differentially. Periodic changes in the cellular DNA and RNA contents were observed through five cell cycles. The $G_{1}$ and $S$ phases of synchronized HeLa $S 3$ cells that contained large amounts of RNA became shorter than those of cells that contained smaller amounts of RNA.
\end{abstract}

The DNA and RNA contents of individual cells can be measured simultaneously by flow cytometry $(1,2,3,4,5,6)$. In this technique, cells in suspension are stained with the fluorescent, metachromatic dye acridine orange(AO) under conditions in which the dye is intercalated into native DNA and orthochromatically fluoresces green, whereas single-strand RNA metachromatically stains red. Using this technique, we previously reported the relation between the cellular RNA content and the length of phases for V79 Chinese hamster cells synchronized by hydroxyurea (HU) (5). The cycle time of V79 cells in balanced growth was about nine hours.

To clarify the intracellular regulation of the cell cycle to examine whether a relation between cellular RNA content and the cycle exists even in cells with a long cycle. In this study, changes in the mean cellular DNA and RNA contents of two populations of synchronized HeLa S3 cells were measured by flow cytometry for five generations.

HeLa S3 cells were maintained as growing monolayer cultures in Dulbecco-Vogt, modified Eagle's medium containing $15 \%$ newborn bovine serum (NBS, Flow Laboratories) in a humidified atmosphere of $10 \% \mathrm{CO}_{2}$ at $37^{\circ} \mathrm{C}$. HeLa S3 cells in logarithmic growth were plated in petri dishes $\left(28 \mathrm{~cm}^{2}, \mathrm{~A} / \mathrm{S} \mathrm{Nunc}\right)$ so that the total cell number could be maintained at approximately $6 \times 10^{5}$ cells per dish for the measurements.

Cells cultured in petri dishes for $30 \mathrm{~h}$ were synchronized by double treatment with HU. At time $\mathrm{t}=0$ (hour), the cells were washed once with medium containing $0.2 \mathrm{mM}$ HU and $15 \%$ NBS (HU medium) then they were cultured again in HU medium. At time $\mathrm{t}=19$, cells were washed twice with medium without $\mathrm{HU}$ (HU-free medium) then were cultured again in $\mathrm{HU}$-free medium. At $\mathrm{t}=29$, cells were treated with $\mathrm{HU}$ as described above, and at $\mathrm{t}=39$, the cells were released from $\mathrm{HU}$.

To obtain cell populations containing relatively small and large amounts of RNA,

Abbreviations used: NBS, newborn bovine serum; HU, hydroxyurea; $\mathrm{CV}^{\prime}$, modified coefficient of variation; $\mathrm{BG}$, balanced growth; $\mathrm{AO}$, acridine orange. 
304

K. Fujikawa- Yamamoto
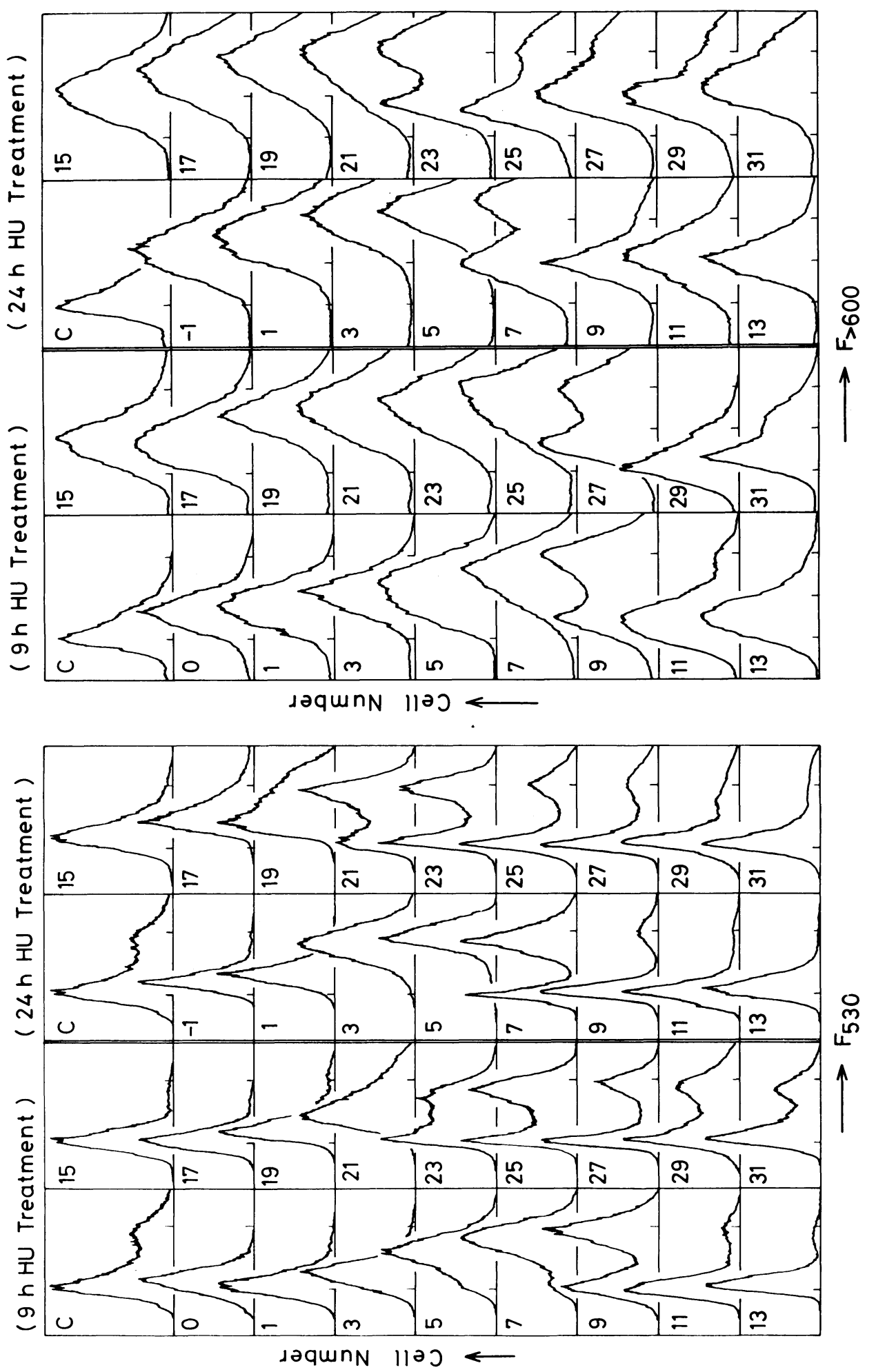


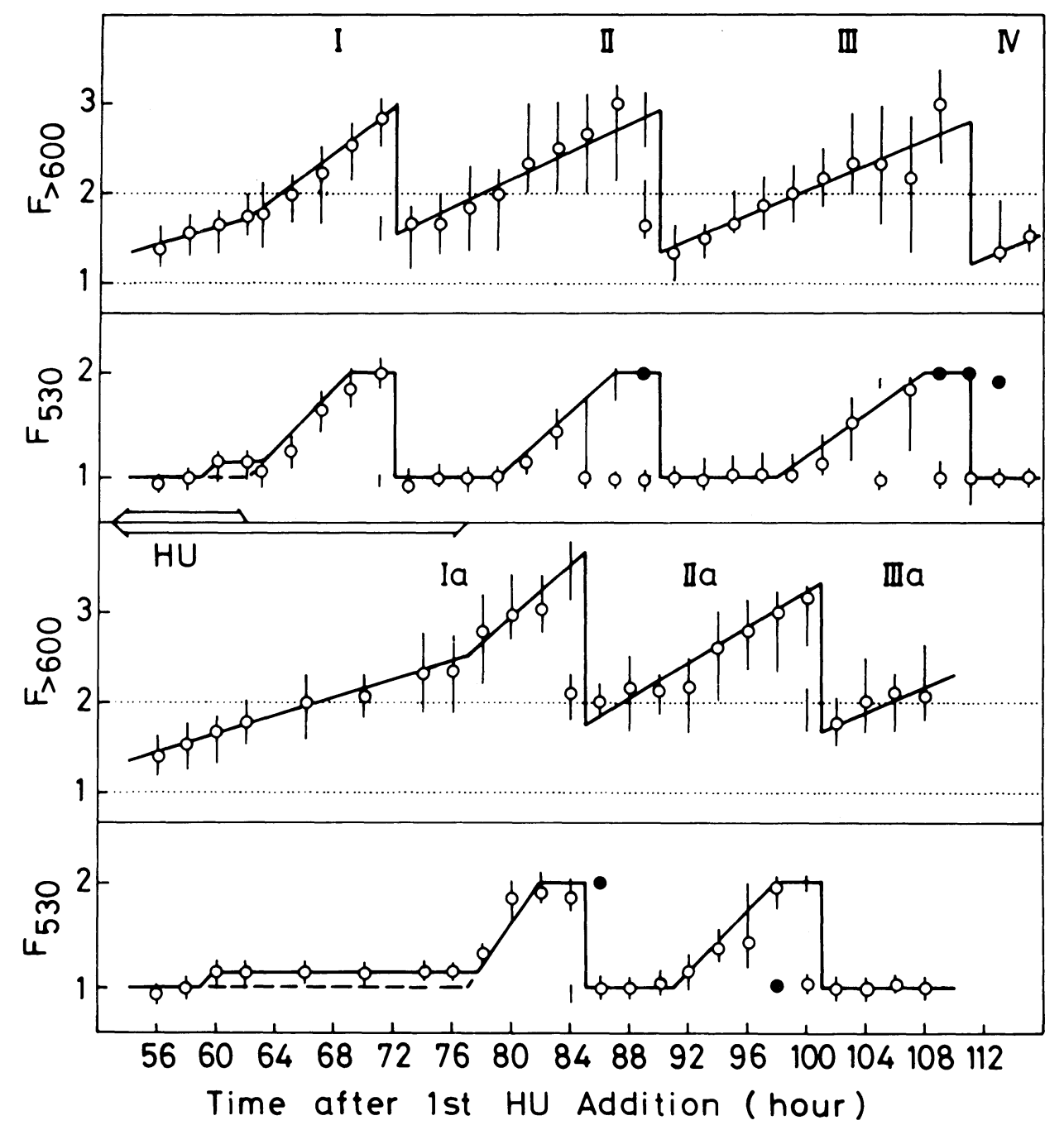

Fig. 2. Changes in $F_{530}$ and $F_{>600}$. Open circles: $F_{530}$ or $F_{>600}$ values for peaks in the frequency distribution histograms. Closed circles: values for subpeaks less than $80 \%$ of the height of the main peak. Longitudinal bars: peak width at $80 \%$ of the main peak height. Half arrows labeled HU: the length of the third HU treatment; arrow above the middle line refer to the upper panel and those below to the lower one. The abscissa gives the time after the first $\mathrm{HU}$ addition and the ordinate $\mathrm{F}_{530}$ or $F_{>600}$ values. Roman numerals $\mathrm{I}$ to IV and Ia to IIIa correspond to single cell cycles from $\mathrm{G}_{1}$ to $\mathrm{G}_{2+\mathrm{M}}$. Solid lines were drawn based on the open circles. Broken lines were added for clarity. Dotted lines represent the normal level (averaged values) of $F_{>600}$ in the $G_{1}$ phase (lower) and the $G_{2}+M$ (upper) phase obtained from the decomposed frequency distribution histograms (5).

Fig. 1. Changes in $F_{530}$ (left) and $F_{>600}$ (right) frequency distribution histograms. These histograms are normalized for peak height. Numbers in the histograms indicate the time (hours) after the third HU release. C: the BG cells (control). The origin of the $\mathrm{F}_{530}$ histograms was shifted. The origin of the $F_{>600}$ histograms was corrected by considering a nonspecific $F_{>600}$ value (6). 
we divided synchronized HeLa S3 cells into two groups. At time $t=53$, when the cells in each petri dish were in $\mathrm{G}_{1}$, one group was treated with $\mathrm{HU}$ for $9 \mathrm{~h}$ and the other for $24 \mathrm{~h}$. At various times after the third $\mathrm{HU}$ release, the cells were washed with PBS $^{(-)}$, then trypsinized and suspended in medium containing $13 \%$ fetal bovine serum (Flow Laboratories).

The amounts of cellular DNA and RNA in these cells immediately were measured as described elsewhere (5). HeLa S3 cells in balanced growth (BG cells) that had been seeded in petri dishes at a relatively low density were prepared and were measured every $12 \mathrm{~h}$ as a sensitivity check of the whole system of measurement.

Changes in the frequency distribution for the relative intensities of green $\left(F_{530}\right)$ and red $\left(\mathrm{F}_{>600}\right)$ fluorescence from AO-stained HeLa S3 cells after the third HU release are shown in Fig. 1. To evaluate the relationship between $F_{>600}$ and the cell cycle parameters $T_{\mathrm{G} 1}, \mathrm{~T}_{\mathrm{S}}$, and $\mathrm{T}_{\mathrm{G} 2+\mathrm{M}}$ (the durations of the $\mathrm{G}_{1}, \mathrm{~S}$, and $\mathrm{G}_{2}+\mathrm{M}$ phases), $F$ values of peaks in the $F_{530}$ and $F_{>600}$ histograms were plotted against the time after the first HU addition (open circles in Fig. 2). The solid lines for $F_{530}$ and $F_{>600}$ in Figure 2 were drawn based on the open circles for $F_{530}$ taking into account the heights of the subpeaks. The solid lines for $F_{530}$ were drawn so that the $T_{G 2+M}$ in every cell cycle was $3.0 \mathrm{~h}$ because it was impossible to detect slight differences in $\mathrm{T}_{\mathrm{G} 2+\mathrm{M}}$ from measurements taken every $2 \mathrm{~h}$.

We concluded that (within the experimental error) the solid lines represent the true progression of the HeLa S3 cell population throughout the cell cycle. Roman numerals I, II, III, IV, Ia, IIa, and IIIa in Figure 2 correspond to cell cycles that proceed from $G_{1}$ to $G_{2}+M$. The duration of each phase in these cell cycles, the $F_{>600}$ values in the early $G_{1}$ phase (the smallest $F_{>600}$ value in a cell cycle), the rate of change in $\mathrm{F}_{600}\left(\Delta \mathrm{F}_{>600} / 1\right.$ hour) and the modified $\mathrm{CV}$ (coefficients of variation) values $\left(\mathrm{CV}^{\prime}\right)$ are summarized in Table 1.

As shown in this table, the cycle time, $T_{c}$, was related to $F_{>600}$; the larger the $F_{>600}$ value the shorter the cycle time. Because the $T_{C}$ and $T_{S}$ values for cell cycle III (Table 1) agreed with those obtained by the ${ }^{3} \mathrm{H}-\mathrm{TdR}$ continuous labeling index method (unpublished data), we concluded that the values for $\mathrm{T}_{\mathrm{G} 1}, \mathrm{~T}_{\mathrm{s}}$, and $\mathrm{T}_{\mathrm{G} 2+\mathrm{M}}$ in cell cycle III were the same as those for BG cells. Since the $F_{>600}$ value in the early $G_{1}$ phase for cell cycle III is 1.35 times of that for BG cells, the RNA threshold

TABle 1. Values Related to the Cell cycle of Synchronized Hela S3 Cells *

\begin{tabular}{|c|c|c|c|c|c|c|c|c|}
\hline \multirow{2}{*}{ Cycle } & \multicolumn{4}{|c|}{ Duration (hour) } & \multirow{2}{*}{$\begin{array}{c}\mathrm{F}_{>6600} \\
\left(\text { early } \mathrm{G}_{1}\right)\end{array}$} & \multirow{2}{*}{$\frac{\Delta \mathrm{F}_{>600}}{1 \text { hour }}$} & \multicolumn{2}{|c|}{$\mathrm{CV}^{\prime}\left(\right.$ early $\left.\mathrm{G}_{1}\right)$} \\
\hline & $\mathrm{G}_{1}$ & $\mathbf{S}$ & $\mathrm{G}_{2}+\mathrm{M}$ & $\mathrm{T}_{\mathrm{C}}$ & & & $F_{530}$ & $F_{>600}$ \\
\hline I & - & (7) & 3 & - & - & 0.11 & - & $\ldots$ \\
\hline II & 7 & 8 & 3 & 18 & 1.40 & 0.08 & 0.27 & 0.45 \\
\hline III & 8 & 10 & 3 & 21 & 1.35 & 0.07 & 0.11 & 0.50 \\
\hline IV & - & - & - & - & 1.20 & - & 0.11 & 0.53 \\
\hline Ia & & (5) & 3 & - & - & 0.12 & - & - \\
\hline Ila & 6 & 7 & 3 & 16 & 1.80 & 0.09 & 0.15 & 0.23 \\
\hline \multirow[t]{2}{*}{ IIIa } & - & - & - & - & 1.67 & - & 0.15 & 0.35 \\
\hline & & & & & $\begin{array}{l}1.00 \\
\text { 3G cells) }\end{array}$ & $\begin{array}{c}0.05 \\
(+\mathrm{HU})\end{array}$ & $\begin{array}{l}0.16 \text { (mean) } \\
0.06 \text { (S. D) }\end{array}$ & $\begin{array}{l}0.41 \text { (mean } \\
0.12 \text { (S. D. }\end{array}$ \\
\hline
\end{tabular}

* The values listed were calculated from Figure 2 . The $\mathrm{F}_{>600}$ values for $\mathrm{BG}$ cells are averaged $\mathrm{F}_{>600}$ value obtained from decomposed $F_{>600}$ frequency distribution histograms for the $G_{1}$ phase $(5,6)$. $+\mathrm{HU}:$ the presence of $\mathrm{HU}$. 
for HeLa S3 cells is within 1.35 times the average RNA content of BG cells in the $\mathrm{G}_{1}$ phase (4); within the threshold, $\mathrm{T}_{\mathrm{C}}$ is constant.

It is clear from Figure 2 that the $F_{>600}$ values of cell populations induced by $\mathrm{HU}$ treatment to have relatively large amounts of RNA decrease in subsequent generations. Within the experimental error, $F_{>600}$ increases linearly in the cell cycle, from $G_{1}$ to $G_{2}+M$, irrespective fo the phase. Therefore, the $F_{>600}$ values in the early $\mathrm{G}_{1}$ phase can be used to examine the relationship between the relative rate of RNA synthesis (the rate of change in $\left.F_{>600}\right)$ and the RNA content $\left(F_{>600}\right)$.

Although our data consisted of only three points, the rate of change in $F_{>600}$ $\left(\Delta F_{>600} / 1\right.$ hour $)$ and the $F_{>600}$ values of the early $G_{1}$ phases were correlated with the correlation coefficient $\gamma=0.91$ and with the regression line, $\Delta \mathrm{F}_{>600} / 1$ hour $=$ $0.033+0.028 \times F_{>600}$. In contrast, the rate in HU-treated cells was constant irrespective of the $F_{>600}$ value and was smaller than that in the absence of HU: It was approximately equal to the value obtained by dividing the cellular RNA content produced during one cycle of these cells in balanced growth by the $T_{C}$ value.

The extent of variation in the early $G_{1}$ peaks in the $F_{530}$ and $F_{>600}$ frequency distribution histograms (a quick guide for the distribution of cellular DNA and RNA in the cell cycle) was calculated by dividing the width of the $80 \%$ peak height by the $F$ value of the peak $\left(\mathrm{CV}^{\prime}\right.$ in Table $1: \mathrm{CV}^{\prime}=0.89 \mathrm{CV}^{\prime}$, for a peak approximated by a normal distribution). The values for $\mathrm{CV}^{\prime}$ indicate that the degree of variation for the RNA content is larger than that for DNA.

Because the properties of a synchronized cell population can be regarded as those of its constituent cells, the data obtained in this study could be summarized as follows: The $T_{C}$ of individual HeLa S3 cells with an RNA content above a particular threshold (about 1.35 times that of $B G$ cells) in the early $G_{1}$ phase is shorter than that of BG cells. HeLa S3 cells induced by $\mathrm{HU}$ treatment to have a relatively large amount of RNA have reduced RNA contents in subsequent generations. The rate of RNA synthesis in HeLa $\mathrm{S} 3$ cells is correlated with the RNA content in the initial $\mathrm{G}_{1}$ phase. And, the degree of variation in the cellular RNA content of HeLa S3 cells in the $\mathrm{G}_{1}$ phase of the cell cycle is larger than that for DNA. These properties of HeLa S3 cells were essentially the same as previously described for V79 cells (5).

Acknowledgments. I thank Dr. Masao Inoue for helpful discussions, Mr. Masami Wada for his technical assistance and Dr. Shizuo Odashima for the gift of HeLa 3S cells.

\section{REFERENCES}

1. Coulson, P., A.O. Bishop and R. LenARDzzi. Quantitation of cellular deoxyribonucleic acid by flow microfluorometry. J. Histochem. Cytochem. 25, 1147-1153, 1977

2. Darzynkiewicz, Z., F. Traganos, T. Sharpless and M.R. Melamed. Conformation of RNA in situ as studied by acridine orange staining and automatic cytofluorometry. Exp. Cell Res. 95, 143-153, 1975

3. Darzynkiewicz, Z., D.P. Evenson, L. Staiano-Coico, T.K. Sharpless and M.R. Melamed. Correlation between cell cycle duration and RNA content. J. Cell. Physiol. 100, 425-438, 1979

4. Darzynkiewicz, Z., H. Crissman, F. Traganos and J. Steinkamp. Cell heterogeneity during the cell cycle. J. Cell. Physiol. 113, 465-474, 1982

5. Fujikawa-Yamamoto, K. RNA dependence in the cell cycle of V79 cells. J. Cell. Physiol. 112, $60-66,1982$ 
6. Traganos, F., Z. Darzynkiewicz, T. Sharpless and M.R. Melamed. Simultaneous staining of ribonucleic and deoxyribonucleic acid in unfixed cells using acridine orange in a flow cytometric system. J. Histochem. Cytochem. 25, 46-56, 1977

(Received for publication, May 9, 1983) 